\title{
Defilement of Girls in Selected Primary and Secondary Schools in Lusaka Province: Implications for Guidance and Counselling
}

\author{
Beatrice Chirwa $^{1}$, Sophie Kasonde-Ng'andu ${ }^{2}$, Kalisto Kalimaposo ${ }^{3}$
}

University of Zambia, Lusaka

\begin{abstract}
The purpose of the study was to examine the implications for guidance and counselling on defiled girls in the education sector. The objectives of the study were to examine the guidance and counselling support services provided to victims of defilement, explore the knowledge base on defilement and whether information dissemination on defilement has reached the primary and secondary school pupils, find out implications for guidance and counselling on defiled girls and assess the guidance and counselling support services provided to victims of defilement in primary and secondary schools of Lusaka province. A mixed method approach was used to conduct this study. Purposive sampling was used to select the sample. Data was collected using semistructured questionnaires, and semi-structured interview schedules to a sample of 90 pupils, 15 parents, 9 guidance and counselling teachers, 9 head teachers, and 3 community leaders. Data was analysed quantitatively and thematically.
\end{abstract}

The study showed that all the participants that is, girls that fell victim of defilement, parents of the girls that had experienced defilement, head teachers, counselling and guidance teachers and the community leaders, were aware about defilement and that their main source of information on defilement was the media. Other sources included sensitisation workshops, friends, neighbours and people around the community. Furthermore, the study revealed that the main perpetrators of defilement were adults and peers outside school. Other perpetrators included teachers in the school, fathers, step-fathers, uncles, elder brothers, and cousins.

As regards to whether the victims of defilement were put on counselling programmes, the study revealed that the girls that had experienced defilement, parents of the girls that had experienced defilement, head teachers, counselling and guidance teachers and the community leaders all acknowledged that such girls were put on counselling programmes. This revelation is quite encouraging at a glance, but the content and quality of counselling provided is yet another aspect that need further scrutiny as it might have a bearing on the counselling programmes provided to the girls.

The study further revealed that the school, family and the community provided support to the defiled girls in the form of counselling and sensitisation programmes which were provided through clubs such as SAFE and AntiAIDS clubs, and peer educators. Furthermore, the study showed that the victims of defilement were assisted by way of taking them to hospitals for medical care and in apprehending the defiler until the time of the court proceedings.

In terms of whom the victims of defilement dealt with directly at school on issues relating to defilement, it was found that they mostly dealt with the head teachers. However, it was also found that to some extent they reported such matters to the guidance and counselling teachers though the support they got was reported not to have been adequate enough. Within the home, it was found that the defiled girls mostly reported such matters to their mothers and sisters and only a few dealt with their grandmothers and cousins. However it was found that the support they received from these caregivers was reported to be adequate enough. Mothers helped the victims by reporting perpetrators of the vice to police and making sure that they (perpetrators) were arrested and subsequently appeared in the courts of law. The study also revealed that girls that got defiled in some instances also dealt directly with the police by reporting the perpetrators.

As regards availability of awareness programmes at school, family and community levels to empower children with child-defilement preventive skills in primary and secondary schools, it was found that such programmes were not available. However, some head teachers, and guidance and counselling teachers argued that such programmes were available in some schools. They cited NGOs such as the Young Christian Association who availed such programmes to the pupils through poems and drama.

Basing on the study findings, the following were recommended: the Ministry of Education, Science, Vocational Training and Early Education through school administrators should engage itself in continuous vigorous educational awareness campaigns on child defilement; schools should strengthen the guidance and counselling section by ensuring that the guidance and counselling teachers uphold confidentiality as victims of this vice 
need teachers who honour confidentiality. This will allow more girls to freely report cases of defilement; traditional practices that are anti-girls such as those that inform girls not to report gender-based violence vis-avis defilement, should be done away with. This could be achieved through community and school initiatives by working in partnership, visiting, and holding talks with traditional leaders on the evils of defilement and its consequences; and that the government through its appropriate organs should mount campaigns aimed at making the law to be more consistent with reality.

Keywords: Defilement, Guidance and Counselling

\section{BACKGROUND}

The study focused on defilement of girls in selected primary and secondary schools in Lusaka province in Zambia. Child defilement is a big challenge in Zambia and has brought about great concern to the Zambian government, the community and NGOs interested in the development of the girl child, especially that it has a psychosocial effect on the education of the girls in particular. The prevalence of defilement differs from one society to another and different for rural and urban populations. Defilement prevalence probably also varies between the rich and the poor, educated and the uneducated, employed and the unemployed. However, there are few statistics available so far that offer such breakdowns. The global prevalence of child defilement has been estimated at $19.5 \%$ for females and 7.9 percent for males according to findings published in 2009 in the Clinical Psychology Review that examined 65 studies from 22 countries.

In Zambia, defilement is an offence contrary to Section 138 (1) of the Penal Code which stipulates that "any person who unlawfully and carnally knows any girl under the age of sixteen years is guilty of a felon and is liable to imprisonment for life" (Chulu et al., 2001:46).

The UN Convention on the Rights of the Child (Article 34, CRC, 1990), to which Zambia is a signatory, prohibits child sexual abuse. Once the rights of a child have been violated, there are various implications to the state of the child. Counselling is therefore needed in such situations.

Despite the many media reports on defilement and the penalties attached to it, the vice has become increasingly a menace to the society. This dilemma motivated the researcher to undertake this study with a view to adding new knowledge to the already existing knowledge on the subject.

\section{Findings AND DISCUSSIONS}

\subsection{Knowledge Base on Defilement and Whether Information Dissemination on Defilement has Reached the Primary and Secondary School Pupils}

As regards to whether information has reached the Zambian populace, the study revealed that the majority (68\%) of the girls that got defiled, the parents/guardians of the girls that had experienced defilement (93\%), all the three head teachers, all the four guidance and counselling teachers/matron and one community member who participated in this study, were aware of and had information on defilement.

As regards the main sources of information on defilement, the girls that fell victim of defilement were of the view that the media was their main source of information on issues pertaining to defilement. This accounted for $28 \%$ of the total number of the girls who responded to this aspect. This finding is actually in line with the many reports in the media (Times of Zambia, February 15, 2014). However, $23 \%$ of the girls that fell victim of defilement, reported the school as being their major source of information pertaining to issues on defilement. The study has further shown that $85 \%$ of the parents and guardians of the girls that had experienced defilement cited the media as their main source of information on child defilement. Other sources included sensitisation workshops, friends, neighbours and people around the community who talked about defilement. Similarly, all the three head teachers and two out of the three guidance teachers proclaimed the media as their main source of information on child defilement. From the preceding discussions, it seemingly stresses the important role the media plays in information dissemination, not only on defilement but on many other issues affecting the community and the country as a whole.

This scenario is very saddening in the sense that the percent difference between the media and the school, though seemingly low, is indeed very significant. One would expect the school to be the cardinal source of information for the girls that had experienced defilement since they spent most of the time in school. It is also not clear why most of the girls (28\%) who had experienced defilement never responded to the issue at hand. 
This finding, which ranks the media as the main source of information on defilement, cannot be taken as a surprise because in Zambia, nowadays, issues of defilement have become the talk of the day on the radio, television and newspapers, to mention a few. However, knowledge of information about defilement is not adequate enough alone; it needs proper application of the information in order to arrive at tangible solutions that would help curb the scourge. Therefore, despite the overwhelming response to awareness of information on defilement by the subjects who participated in this study, there is need for interested parties on issues surrounding defilement of girls in schools to collaborate their efforts in finding workable interventions that would help reduce cases of defilement or completely eradicate defilement of girls' in schools. Nonetheless, suffice to mention that information dissemination could be said safely, that it has reached primary and secondary school pupils in Zambia considering that such information was disseminated through the radio, television and newspapers which are the most common form sources of information in the country.

As regards to what the participants of this study knew or understood about defilement, their views varied. For the parents of the pupils that had experienced defilement, 50\% defined defilement as an act of having carnal knowledge of a minor whereas $18 \%$ defined it as a crime that should be reported to the police. Further, $10 \%$ of the parents/guardians said defilement was a case where the perpetrator could be afforded the chance of obtaining bail while one parent/guardian was of the view that defilement is an act of touching private parts or sleeping with a minor. On the other hand one of the head teachers described defilement is an offence one commits when he/she has sex with a child under the age of sixteen (16) years old" while the other defined it as having sex with a young person under the age of sixteen (16) years old. Yet the community leader defined that defilement is an act that involves unlawful carnal knowledge with a girl who is under the age of sixteen (16) years old. Although defilement is defined in different "words" by the different respondents in this study, it all points to one thing, that defilement is having carnal knowledge of a minor. In Zambia, this offence currently attracts a non-mandatory maximum life in prison while an attempt to defile a child attracts a non-mandatory of 14 years imprisonment (WLSA, 2001). Notwithstanding the above stated penalties, offenders who commit this serious crime are almost not sentenced to life, even where a very young child is defiled. In many instances, offenders' getaway with three, four or five year prison terms which makes Section 138 of the Zambia Penal Code in its current form exceptionally inadequate and irrelevant considering the seriousness of sexually abusing a young girl (WLSA, 2001).

According to WLSA (2001) they argue that the whole process needs amendment. They advocated that defilement of girls aged under 14 years must attract a death penalty. They further contended that the government of the republic of Zambia should also institute a law on defilement of the aged. They asserted that defilement should not only be restricted to young people but also cover the aged. Equally important an attempt to defile a girl under the age of 14 years should be revised so that it attracts a penalty of life in prison. This would inculcate fear in the "would" be defilers and in turn it would help the government control the vice. In some instances defilers are reported to defend themselves arguing that they reasonably thought that the girl was above 16 years old. This utterance in its own should not be given room by those in authority and dealing with issues pertaining to defilement.

Nevertheless, the variations in responses in the understanding of what defilement is makes it difficult for the multitude to recognise and report effectively on it. There is, therefore, need by the government kame known or to make clear this term for the Zambian populace to really understand what it entails. There should also be in place some form of "universal definition" that should be adopted to ease the understanding and foster reporting on the scourge by the general public.

As regards information provision about defilement by parents/guardians of the girls that fell victim of defilement, the study has shown that $83 \%$ of them provided such information to their children. Two head teachers out of three that participated in this study also retorted that they availed information on defilement to various groups like pupils and parents. This information includes telling parents to refrain from leaving their children in the care of other people other than the usual guardians and training children to refrain from receiving things from people they did not know. The school guidance and counselling teachers/matrons also provided information to the pupils and parents alike. This information is provided through individual counselling and sensitisation programmes to the pupils. However, one of the guidance and counselling teachers/matrons refuted that there was no such a provision in their school because resources and time were not allocated specifically for this activity by the school. 
One of the participants, the guidance and counselling teacher/matron, revealed that their school did not provide information on defilement to pupils and parents. This finding may be true in the sense that at the time of data collection, the researcher did not find on the school time-table some time allocated to guidance and counselling lessons although some of the guidance and counselling teachers reported that their schools had allotted some time for this subject on their school time-table.

However, from the above discussion it could be deduced that parents, head teachers and counselling and guidance teachers do make efforts in providing information to the pupils and other members of the society on defilement. The only aspect not known is the extent to which this information is provided to pupils and the society as a whole.

In terms of how the community perceived defilement, the guidance and counselling teachers/matrons were of the view that the community's understanding of defilement was that it is an act where a girl is forced to have sex with an elderly man or boy. Similar sentiments came from the community leader. These reactions clearly shows how bitter the community is about the evils of defilement. As such immediate remedy to the issue should be found before "all" the girls are psychologically and/or spiritually affected by the scourge.

This study has shown that in terms of when the victim fell prey to defilement, most of the pupils (91\%) fell victims in the year 2014. The reason for this may be that these pupils were the ones that had experienced defilement at the time the researcher was collecting the data. There could have been earlier cases but have not been reported due to lack of information of such children as they could have been out of school by then. However, the argument still remains that it seems every year cases of defilement keeps on rising in Zambia. This finding is similar to that of Kenya where Kenya's People Daily reported that nearly every 30 minutes a child was raped. It also reported that 38 percent of children aged under 18 years old were sexually abused. Further, The Chambers of Justice report of 2005 "Defilement Index" showed that incestuous defilement was responsible for almost 75 percent of abuse against young girls in urban areas. One of the reasons cited for this was the demented thinking of thousands of men in Sub-Saharan Africa including Zambia, who believe that having sex with a little girl or minor will cure HIV and AIDS. (http://www.cartercenter.org/peace/human_rights/ defenders/countries/kenya.html).

As regards to how the girl got defiled, $18 \%$ of the defiled girls said that their boyfriend took them to their house where they ended up having sex whereas 16 percent reported that it happened when they went for a fun fair and on their way home stopped at a friend's house where it happened. However, $14 \%$ narrated that the incidence happened on their way home when a stranger abused them. From the information above, it is clear that such things happen when the girls were alone away from their parents/guardians. It is therefore imperative for the parents/guardians to ensure that these children are taught to be weary of the tactics used by the defilers so as to safeguard themselves from defilement. Further, the school should play a pivotal role in sensitising the pupils on issues surrounding defilement through the guidance and counselling teachers.

In terms of the age at which children fell victims of defilement, most of the respondents who fell victim of defilement reported that they were defiled at the age of between 13 and 14 years old. However, $28 \%$ of the respondents reported having been defiled at the age of 15 years old and above. Like the girls that had experienced defilement, the majority of the parents $(48 \%)$ whose children were defiled also reported that most of their children got defiled at the age of between 13 and 14 years old while $14 \%$ of the parents each indicated that their children got defiled at the age of between $11-12$ and 15 years above respectively. It seems that the most common age group that gets defiled is that just before adolescent age. The reason could be that at this age the girls would like to exercise liberty of their lives which end them up in many instances into the wrong hands. As such it is among this age group that the guidance and counselling teachers or matrons should intensify their guidance and counselling services so as to mitigate some of the problems the girl pupils face as regards defilement issues. Furthermore, counsellors should train the girls on how to identify the "would" be perpetrators of defilement and provide them with skills to overcome such persons. The counsellors should also put in place a number of workshops and sensitisation programmes on sex education and sexuality in order to help the girls in school. Failure to do so would only contribute to the ever rising numbers of defilement cases in Zambian primary and secondary schools.

In terms of the grades that mostly got defiled, the study has shown that the vulnerable grade was that of grade eight (27\%) and grade seven (14\%). Head teachers also reported similar results as those of 
the girls that had experienced defilement. According to the head teachers, most of the girls get defiled mostly between grades $8-9$. The reason advanced for this was because at this grade level, the girls were still young and did not know to "strongly" say no to sex. However, one of the head teachers was of the view that girls get defiled between grades $10-12$ because of their human (physical) development. The reason for this situation could be attributed to the fact that at these grades, pupils were moving from childhood to adolescence which is a very critical stage of human development.

The study has also shown that the main perpetrators of defilement were adults outside school as reported by $30 \%$ of pupils who had experienced defilement. Furthermore, $31 \%$ of the parents of pupils that had experienced defilement, one out of the three head teachers, two of the school guidance counselling teachers/matrons and one community leader also attested to this finding. Other perpetrators include teachers in schools although in a minimal number, biological fathers, step-fathers, uncles, elder brothers, and cousins. The above findings conform to Armstrong (2013) who also reported that almost 90 percent of the victims of rape, defilement inclusive, reported that the perpetrators were known people who include biological fathers, step-fathers, uncles, brothers, cousins, neighbours, strangers, and priests including teachers in the school. It is, however, saddening to note that even the teachers who are supposed to spearhead the fight against defilement are the ones found practising it.

Strangely enough, these perpetrators were in most cases not arrested or taken to court. This in its own is a drawback to most of the victims of defilement as they feel that despite their reporting to the appropriate authorities, nothing is being done on the perpetrators. Where cases were deliberated, it took too long for the case to be dealt with and in many instances the culprits is made to be coming from their homes thus not feeling any pain as regards to the offence they had committed. This frustrated the victims reporting their cases to the responsible authorities. There is, therefore need to stiffen the laws regarding defilement because it seem like the current laws governing defilement are not punitive enough because people continue committing the same crime day in and day out.

The above scenario is really uncalled for and essentially calls for interventions in order to curb the scourge. It therefore, requires combined efforts from all stakeholders, the community and especially the school through administration to find ways of imparting knowledge, and training the girls with skills pertaining to identifying the would-be defilers and how they could avoid becoming victims of defilement. This can, nonetheless, be achieved through proper guidance and counselling programmes which should be mounted in communities, and especially in schools.

However, the study revealed that most pupils fail to report issues on defilement as they have no faith in the teachers dealing with guidance and counselling in school. They claim that these teachers lack confidentiality and that once a case is reported, it is likely that it may be disclosed to other pupils in school. The above finding is in line with Makumba (2013) who in his study on "The status of guidance and counselling provision in selected basic schools in Mumbwa district of Central Province of Zambia found that the majority of pupils did not report their problems to guidance and counselling teachers but to their class teachers because they believed that the guidance and counselling teachers did not keep confidentiality. This allegation is also supported by Mutie and Ndambuki (1999) who argued that nothing impacts on the outcome of a counselling session more than the counsellor's attitude - either positive or negative. Positive attitude can be learned and practiced. It includes respect, sincerity, unconditional positive regard, empathy, and self-disclosure. The only problem is that pupils prefer counsellors who have the above qualities which most of the guidance and counselling teachers do not possess.

In Zambia for instance, school guidance and counselling is left in the hands of the teachers who are already overloaded with other teaching subjects. When school counselling started in secondary schools in Zambia there were no trained teachers to take up guidance and counselling in schools. The only available training was in form of workshops and seminars to orient the career teachers. As a result new scale of problems such as defilements, child headed homes, drug and alcohol abuse in schools have come to the platform. It is difficult for teachers who are not trained in guidance and counselling to solve these problems. Available literature closely related to this study is that of the reentry policy. According to Mutombo and Mumbuna (2010) pupils who fall pregnant and later go back to school after giving birth (re-entry) were not provided with guidance and counselling services at the schools where they went. It was also found that despite the availability of guidance and counselling 
facilities, teachers responsible for guidance and counselling were not supportive to the girls. The girls in the study stated that they were supported by some teachers out of their own good will and not through the guidance and counselling service section. The above data may, in a way, substantiate as to while defilement cases keep on rising among girls in primary and secondary schools in Zambia. These pupils lack the knowledge and skill of identifying and protecting themselves from the people who are likely to defile them.

\subsection{Implications for Guidance and Counselling on Defiled Girls in Primary and Secondary Schools}

The study has shown that defilement has impacted negatively on the girls in schools. The study has shown that $87 \%$ of the girls that fell victim of defilement were of the view that defilement disturbs them mentally and affected their school performance while others felt that it made them feel like committing suicide, especially when they came into contact with men. They felt men were the same and that any time they met a man they were in fear that the same "thing" might happen to them again. However, some of the girls that fell victim of defilement were of the view that defilement impacted on them negatively because it made them become aggressive and at times mute. The above findings conforms to Gwitira (2015) who argues that the long term consequences of child abuse are many for both the state and the victim. Studies conducted elsewhere have linked visual and hearing deficit, emotional disturbances and low self-esteem, aggressive tendencies and other psychological disorders which include mental, physical and health care as some of the long term consequences of child abuse. For the government, there will be need for more financial resources to meet the law enforcement and judicial administration of cases. As discussed above, it could be stated that the act of defilement is indeed costly on the part of the survivor and the nation as the demands for processing it are too high. To all these, guidance and counselling is prime because if pupils are well equipped with knowledge and skills on defilement, they would be in better position to avoid becoming victims of the vice. Thus there is need to strengthen the guidance and counselling services in schools through training of counsellors in modern techniques.

Chanda (2003) reported the school counsellors must have skills in problem solving, decision making and crisis interventions for their clients to benefit from guidance and counselling services. It should be noted that guidance and counselling covers a wide range of problems such as educational, health and environment, therefore the need to have qualified and trained school counsellors. However, despite the fact that guidance and counselling services are provided in schools it has not been easy for the providers to provide these services because of few trained counsellors in schools and lack methodology to use in the process of providing counselling and guidance to the pupils. Sexton et al. (1997) argue that matching of clients and counsellors does not result in in increased efficacy. Furthermore, the old adage, "counsellor know thyself" does not seem to hold true. They also state that currently there is no systematic research that suggests that counsellors improve their work by receiving personal therapy, becoming more self-aware, or learning about themselves.

Whinston \& Coker (in Press) also argue that what do seem to be important counsellor contributions to effective counselling are a level of skilfulness, that is competence rather than experience, cognitive complexity (ability to think diversely and complexly about cases), and ability to relate and rationally match with the clients with whom they are working (Whiston \& Coker). The above sentiments are clear testimony that for child defilement to be conquered there is dare need to train counsellors in schools in modern methods of counselling. This implies doing away with the traditional methods of counselling deemed to be inappropriate in the modern times. Methods pertaining to traditional and cultural norms that prevent open discussion on issues of sex and sexuality should be done away with so that they open room for pupils to freely discuss and report issues relating to defilement to the relevant authorities.

Globally, there is need for schools to adapt to the ever changing world of technologies and problems that come with it through training guidance and counselling teachers in modern techniques of counselling. This calls for the guidance and counselling teachers to acquire new knowledge and skills on how to handle different types of counselling needs of the clients including defilement. This will definitely help make guidance and counselling in schools to gain the recognition it deserves.

As regards to advice to the girls that had not yet experienced or become victims of defilement, the study has shown that the girls that fell victim of defilement advised those girls that had not yet experienced defilement never trust anyone no matter how close their relationship may be, even their 
closest relatives and that they should refrain from moving around at night, especially when they were lonely as this attracted the attention of the "would-be" defilers. Furthermore, some of the girls that fell victim of defilement (9\%) were of the view that those girls who have not yet experienced defilement should not relent to report suspicious persons to their parents/guardians and that they should be on the look-out all the time. Other advices included that girls should learn how to dress properly, not wearing short or tight clothing's as these attracted the attention of men. This finding is in line with the media report in the Times of Zambia of March 5, 2012 in which it was reported that the poor dressing contributed to the increase of defilement cases in Zambia.

Indeed, the current way of dressing, especially among teens leaves much to be desired. Modern children have lost their cultural values and traditions which in most circumstances has made them find themselves in unprecedented troubles such as defilement. In view of the above findings, it is the responsibility of the guidance and counselling teachers and matrons to vigorously counsel the girls in schools about the good morals if they were going to help the girls escape the scourge of defilement. Furthermore, counsellors should take an initiative to hold several sensitisation meetings on the dress code of the pupils and with their parents. It is believed that in most of the houses that these children come from, they are left to decide on their own on what to dress or wear. Their parents/guardians just sit back until such eventualities like defilement became evident in their homes.

As regards to the advice given to those girls that got defiled, $32 \%$ of the girls that had experienced defilement advised that these pupils should not sympathise with the defilers but that they should report matters of defilement to appropriate authorities so that applicable action can be taken against these people. The other notable advice was that such girls must not blame themselves but must go for counselling because through this process they are likely to receive comfort. Furthermore of the girls, however argued that such girls "should just pray to God and they will recover from the trauma. However, some of the girls advised that girls that got defiled should get medical and psychological help. A medical report was seen as the most important thing to do considering the advent of noncurable diseases like HIV and AIDS. This finding conforms to (WLSA, 2007) who in their study on "Women's Sexual and Reproductive Rights and HIV /AIDS Transmission in Zambia" argued that HIV and AIDS have many other devastating consequences especially on the lives of women and girls. For if the victim obtained a medical report she will be aware of her status and live a positive life. Murphy and Young (2005), in their study on "Sexuality in Children and Adolescents with Disabilities" also argued that sex education empowers even adolescents to enjoy personal sexual fulfilment and to protect themselves from abuse which include defilement, unplanned pregnancies and HIV and AIDS.

As regards to how the parents were informed on the ordeal, $78 \%$ of the victims of defilement reported that they personally told their parents/guardians while seven $\%$ of the girls reported that their friend told the parents and 6\% indicated that the neighbor revealed this information to their parents. Like the responses from the girls that got defiled, the majority of the parents, $66 \%$ stated that they came to know that their child had been defiled through their children who reported themselves whereas $18 \%$ reported that they got such information from other persons within the community they lived.

However, one of the parents reported; "I found my brother naked in my daughter's bedroom that is how I came to know that my daughter had been defiled". From the above, it is evident that girls reported to their parents/guardians once they became victims of defilement. What is not known is whether the same girls did report such matters to the school authorities through the guidance and counselling teachers because so far there is no mention of the guidance and counselling teachers/matrons taking the matter to the parents of the girls. There is therefore need for the guidance and counselling teachers/matrons to fully engage themselves in investigations as regards to defilement as soon as they suspected that the girl might have been defiled and deliver the same information to the parents/guardian of the girl so that necessary action could be taken against the defiler. May be the reason why pupils were unable to disclose such information to the school authority was the bureaucracy that they passed through, especially that of lack of confidentiality by most school guidance and counselling teachers. This finding was also echoed by Makumba (2013) where he reported that despite the fact that guidance and counselling is provided to pupils, 55\% of the pupils reported that they never reported their problems to the guidance teachers but preferred to report their problems to their class teachers because they believe that guidance and counselling teachers never kept confidentiality. He further argued that the lack of keeping confidentiality was attributed to the 
lack of training in guidance and counseling on the part of teachers. In view of the above, it is, therefore imperative to train guidance and counselling teachers on matters related to confidentiality as some cases such as those of defilement are very sensitive in nature. It is also necessary that counsellors make decisions for treatment based on both personal experience gained as a result of clinical practice and external evidence based on research studies.

The study has also shown that the reactions of the parents upon hearing that their child had been defiled was pathetic. Like one of the parents/guardians who lamented thus: "I was speechless, had no words and no strength" and another one said, "I wanted to kill the perpetrator; I felt like wanting to die". However, some parents reported that they confronted the perpetrator and took him to the police. One female parent whose child was defiled by a biological father reported said that she reported the case to the police and that her husband was since arrested. It should be noted that parents/guardians of the girls who fall victims of defilement do try by all means to take action and in some instances they take such cases to appropriate authorities but the processes are too long that at times they easily withdraw. The above findings are in line with WLSA (2012) who in their study on "Women's Sexual and Reproductive Rights and HIV /AIDS Transmission in Zambia" discovered that the formal court system is frequently inaccessible. Police officers may decline to refer a case for prosecution where they do not feel that adequate evidence exists. Complex and lengthy court procedures may also deter victims of defilement from pursuing remedies in court.

Furthermore, given the sensitive nature of the topic and taboos against speaking about sex in Zambia, young girls are likely to feel inhibited from speaking honestly. Police, prosecutors, and courts strongly prefer physical evidence in sexual offence cases, and this is generally difficult to come by given the scarcity of equipment to analyse DNA and the many factors that prevent most girls from going to the police or a hospital right away.

Another obstacle to redress for girls who experience defilement may arise from their families' preference for resolving the matter out of court. Families sometimes pressure the perpetrator, if not a family member to the victim. In the face of widespread poverty, some families would rather seek compensation in the form of financial support or marriage than pursue a criminal prosecution that may have little likelihood of success. Other families may seek a settlement out of court to protect their children from the trauma of participating in public court proceedings. Besides, lack of support from the victims or their families at any stage of an investigation or trial normally ruins the prosecution and prevents the victim from obtaining legal redress.

Regarding the reaction from the school and the community, the majority of the parents/guardians, $62 \%$ stated that there was no reaction from the school and $38 \%$ of the parents/guardians testified that there was no reaction from the community due to the fact that they were not aware about the defilement case. In other words, the issue was kept as a secret. This finding conform to WLSA (2012) findings where they argued that one of the most important barriers may lie in the reluctance of girls who experience sexual abuse to report it. Most instances of defilement sexual violence and harassment against girls in schools including defilement are never reported. Failure in reporting sexual violence cases was because most of the victims were not aware of school policies or procedures to address the abuse or did not view what had happened to them as an offense. Further they felt that nothing would be done about what had happened and also feared that they would be blamed for the sexual abuse they had suffered. The stigma that attaches to victims of sexual violence which include defilement in Zambia contributes to a "culture of silence" that encourages survivors to refrain from speaking about the sexual violence they have suffered.

Nonetheless in some instances where the case was known to the public, the school and the community helped the parents of the defiled child in apprehending the culprit. However what happens thereafter as reported by most of the respondents in this study leaves much to be desired. These cases are never handed in to the courts and in many instances the defiler is left free. This has resulted in people feeling that it was not useful to take such cases to the appropriate authorities as it never yielded the expected results. This outcry calls for stiffer rules on how to deal with cases of defilement if the scourge was to be reduced.

Training is vital in the field of guidance and counselling so as to equip the counsellors with the necessary knowledge and tools to counsel pupils in schools. This would in turn help the guidance and counselling teachers/matrons learn ways or find steps to take into account when they are made aware that a girl has been defiled. This study, has shown that all the three head teachers that participated 
indicated that they had trained guidance and counselling teachers in their respective schools. They stated that these teachers are sent for training and also attend workshops in order to advance their counselling skills. This aspect is indeed very cardinal considering the fast growing social and economic developments taking place in the modern society which if counsellors are not availed with the latest skills would make them fail to contend the ever emerging issues surrounding the communities such as those on defilement.

\subsection{Support Services Provided to Victims of Defilement in Primary and Secondary Schools}

As regards to whether the victims of defilement were given any support, the study had shown that $50 \%$ of them reported that they were put on counselling programmes while $15 \%$ did not receive counselling at all. These girls were aged between 13 and 15 years old respectively.

However, some girls aged between seven to nine years old and those aged between 10 to 12 years old, representing $11 \%$ and $10 \%$ respectively reported that they were not put on any counselling programme. The failure by the counselling and guidance teachers to put the girls on counselling programmes shows how ineffective the counselling services are in schools. One would be think that the guidance and counselling teachers would concentrate most in providing counselling to this age group as it is in the early stages of the adolescent, a period which need more guidance on social related issues including defilement.

The Zambia Journal of Teacher Education (1995) recommends that schools should use techniques and methods in guidance and counselling which help the learners to maximise their intellectual potential and be able to enhance solving their own problems. Phiri (2006) observed that teachers alone cannot handle the learners effectively unless they are assisted by the parents, family members and the community as a whole. It should therefore be acknowledged that for guidance and counselling to be effective in schools it needs support from the government and other stakeholders in the education ministries, including parents and the community as a whole.

An issue regarding to whom the victims of defilement directly dealt with in school, at home, and within the community concerning their defilement experiences was also raised in this study. An assessment of the support the victims of defilement received from the above institutions was equally sought from the girls.

As regards to whom the victims of defilement directly dealt with in school on issues related to defilement, most of them reported that they confided such information to "other" persons in school. However, it was also found that the victims of defilement reported their cases to the head teacher and a few of them to the guidance and counselling teachers/matrons. Reasons for few pupils reporting cases of defilement to the guidance and counselling teachers/matrons was that they believed that the guidance and counselling teachers lacked confidentiality and that if one reported to them about it, they could easily disclose such information to other pupils in school. This they said, brought about segregation, intimidation, rejection and stigmatisation from their peers. This scenario has also been cited by Makumba (2013) where he found out that 55\% of the pupils preferred to report cases of harassment, rape, including defilement to their class teachers than the guidance and counselling teachers/matrons. Pupils also fail to report to the schools authorities such as the head teachers and guidance and counselling teachers/matrons because these officers were in most cases unfriendly and unreceptive. It is saddening to note therefore that school administrators such as the head teacher or guidance and counselling teacher who may possibly appear to be the appropriate people to report to, were inhospitable and impervious. WLSA (2007) also found that lack of knowledge and information on where to report issues relating to sexual abuse has discouraged girls from reporting.

However, for the few pupils that revealed the information to the head teachers and the guidance and counselling teachers/matrons $(10 \%)$, they were of the view that the type of support that the head teachers and the guidance and counselling teachers/matrons provided to them was very helpful because they received the necessary counselling and were also given moral support. The head teachers further explained that they have other stakeholders who they work with in the quest to support the defiled girls. These include the NGOs like FAWEZA, YWCA to mention but a few. Furthermore, the school involves both the parents/guardians and the children in discussing issues as regards defilement. Although this being the case, a further scrutiny of the findings shows that there is little information on guidance and counselling that is provided to the pupils by the head teachers and guidance and 
counselling teachers/matrons considering that only a small proportion (10\%) out of the 59 pupils who respondent to this issue made their way to report defilement cases to their head teachers and the guidance and counselling teachers/matrons. As earlier noted, the pupils' failure to report such cases the school authority was mostly hampered by lack of confidentiality by the officers handling such cases. This in itself calls for proper training of the guidance and counselling teachers in modern skills on how to handle such cases if the pupils were going to be free to report to them and thereby receive the needed information on how they could guide themselves against the perpetrators of defilement. This can be achieved by applying the ERB technique which is a scientifically-based investigation tool concerning the effectiveness of a treatment, intervention, programme or practice. This tool was traditionally viewed as one that deals with medicine alone until around 2002 when it was seen as a standard practice in other human service which include education, mental health, poverty reduction, crime prevention and economic development (Coalition for Evidence Based Policy, 2002). Sexton (1997) also argues that evidence-based practices can provide a source of clinical knowledge that can increase a counsellor's effectiveness with clients, become a basis of professional education and counsellor development and serve as a unifying force for the profession that will set the agenda for the next evolution of counselling.

It should be noted that counselling is becoming more empirically based in its delivery and thus counsellors are expected to meet their varied clients and abandon practices that are not effective. They need to identify and apply evidenced based procedures with their clients. Further Reynolds (2000) argues that counsellors make decisions for cure founded on both personal experience and external evidence from the research studies. The above assertions calls for counsellors to apply this same method in issues regarding defilement of the girls in schools. They need to be abreast with the latest methods of imparting knowledge and skills to the unsuspecting girls on how to identify and protect themselves from these unscrupulous men in the society. However, the problem may be that most counsellors are not sufficiently trained in accessing and applying these procedures. Perhaps this could be due to lack of preparation and that most people considered counselling as not being a science field.

It should be realised that as children leave the childhood to adolescent, they experience a lot of things in their lives; their expectations are high and if not well guided may lead them into circumstances like what these girls had experienced. There is, therefore, dare need for the counselling and guidance teachers to abreast themselves with new techniques of counselling that are friendly and allows freedom and make children who are faced with problems of sexual abuse which include defilement to confide in them. Through counselling, pupils will learn skills of recognising the perpetrators of such devices. This will in turn help reduce cases of sexual abuse among the girls in school.

At home, the study has shown that most of the children who fell victim of defilement reported their cases to their mothers and immediate sisters $(54 \%)$ on matters concerning defilement. A further $26 \%$ confide to their grandmothers. Furthermore some of the victims of defilement rested their cases in their aunts. The reasons behind this as reported by the victims of defilement was that these people were easy to narrate to and that they were caring unlike the male parents. As regards to assessment of the support that they received from their mothers, the study has shown that it was very good in that these victims were taken to the police to report the incidence and that the perpetrators were arrested whereas they were also counselled and comforted. One interesting part is that it was also found that some of the victims were tested for pregnancy and HIV. Grandmothers on the other hand, equally made sure that their granddaughters were tested for HIV and pregnancy and also counselled and showed love and care for the victims. One parent could not hesitate in revealing her action upon knowing that the child was defiled. She thus said "concerning her bruises on the vagina, I applied first aid by putting her in cold salt water". This revelation shows how caring the female folks are towards their children. However, this alone was not enough. It needed the parent/guardian to apprehend and have the culprit arrested.

Generally, this study has shown that the girls that got defiled, the parents of the girls that had experienced defilement, the head teachers, the counselling and guidance teachers and the community all acknowledged that the girls that got defiled were put on counselling programmes. This revelation is quite encouraging at a glance, but the content and quality of counselling is yet another aspect that might have a bearing on the counselling programmes provided to the girls that got defiled because the study revealed that most of the guidance and counselling teachers in these schools were not trained in this field. It is argued that for guidance and counselling to be successful and effective in schools, there 
is need to have teachers who have the skills and knowledge about guidance and counselling. The Zambia Journal of Teacher Education (1995) argued that effective guidance and counselling practice in schools in Zambia highly depends on the skills and knowledge of the teachers involved in counselling.

In Zambia, school guidance and counselling is left in the hands of the teachers who are already overloaded with other teaching subjects. New scale of problems such as defilements, child headed homes, drug and alcohol abuse in schools tend to be difficult for teachers to contend because they are not trained in guidance and counselling to solve these problems. Available literature closely related to this study is that of the re-entry policy. Mutombo and Mumbuna (2010) did a study on the re-entry policy in Zambia's primary and secondary schools. The findings of this study revealed that the pupils who fall pregnant and later go back to school after giving birth (re-entry) were not provided with guidance and counselling services at the schools where they went. The study also revealed that the guidance and counselling facilities that were available in these schools were not supportive to the girls. The girls in the study stated that they received support from some teachers out of their own good will and not through the guidance and counselling service section. However, Phiri (2007) observed that teachers alone cannot handle the learners effectively unless they are assisted by the parents, family members and the community as a whole. In other words, he contends that the provision of guidance and counselling should be holistic.

Like the girls that got defiled, the majority of the parents/guardians $76 \%$ attested that these girls received support from other family members. The support mostly provided to these girls was in form of counselling and empathy. The other form of support that the parents/guardians of the defiled girls gave to the girls was by way of apprehending the culprit and taking the perpetrator to the police. However, some parents/guardians did not support these girls any form. Their argument was based on the fact that they had just learnt about it and had not yet studied the circumstances under which it occurred. Yet some of the parents/guardians were of the view that they could not support such children because the information was kept secret.

Further, the study has shown that a child was denied support by other family members because her mother reported the husband who defiled the child to the police. They were felt that the mother should not have reported the husband to the police since this act was done by the biological father and that they should have settled the matter within the home without the involvement of the police. Surely, the above statement from the relations was very devastating. What the mother did was actually in the right direction and was doing it to protect the rights of the child. The National Gender Policy in which gender based violence is one of the primary areas of concern, has put in place measures aimed at eliminating violence against women and children (in this regard the girl child) by way of encouraging victims, through appropriate mechanisms, to report cases of all forms of violence and sexual abuse to the relevant law enforcement agencies (WLSA, 2001). It might, therefore, be argued that the mother to the defiled girl was acting within the stipulated laws regarding the offence that was committed by her husband. She had all the right to report the case to the policy. In any case the action by the mother acts as a warning to the ("would be defilers") be fathers who might think of defiling their children.

As regards to assessment of the support provided to the girls that fell victim of defilement, $54 \%$ were of the view that the support rendered to them by their mothers was very good in that they helped take them to the police and had the executor arrested. Equally, (11\%) were of the view support given to them by their grandmothers and cousins was adequate because they were taken to the hospital where they were tested for pregnancy and HIV. From the issues that have emerged in the above discussion, it may be said that the defiled girls did receive support from their family members.

In terms of the community, the study has revealed that $39 \%$ of the girls that got defiled dealt directly with the police as a community. The reason for this may lie in the sense that they believed the police was and had the authority to apprehend and arrest the perpetrators of the vice. They also believed that the police were well trained in these issues and have adequate information and skills to deal with cases of defilement. Nonetheless, $37 \%$ of the girls did not deal with anyone within the community. The assumption underlying this action could be that once such information was openly availed to the community, the girl might be segregated, discriminated and maybe stigmatised. It is also soddening to note that very few girls (4\%) dealt with the NGOs like the Young Women Christian Association (YWCA) which in most cases help out the girl child in almost all the spheres of the social, economic 
and spiritual well-being of the girls in Zambia. The above findings may be an indication of how little trust the girls have for the community. It might also imply that the community does not care about the welfare of "others" in the community.

In terms of support from the community, the study has shown that like the girls that got defiled, parents/guardians also were of the view that the defiled girls received little or no support at all from their friends who in this case were the members of the community. The reasons advanced were that the friends or community did not know about their case. This sentiment was exactly what the defiled girls themselves had alluded as discussed earlier on. However, a few parents reported that the girls do receive support from their friends which is in form of love, care and helping in apprehending the perpetrator.

From the above discussions it may seem that the girls that get defiled do not have adequate support from the community. However, scrutiny of the above discussion has some revelation that support is "somehow" provided to the girls; the only problem may be that such information is concealed or kept secret by the parents and the defiled girls themselves. There is therefore need for counsellors to map up strategies to sensitise the populace on the importance of sharing such information as this would help in increasing awareness on issues pertaining to defilement to the girls and the community as a whole and thereby help minimise cases of defilement or totally eliminate it. This could be achieved by promoting awareness through campaigns to change harmful and negative cultural practices in society especially through health and media personnel, the police and other security and defence agencies towards issues with regard to defilement.

Regarding the assessment of the support provided by the community to girls that fell victims of defilement, $19 \%$ of them assessed the support that was provided to them by the police as being "good because after presenting their cases to the police they felt relieved as they were assured of apprehending the suspect. Furthermore, seven per cent were of the view that the support given to them by the police was "good" in that the police advised them to go to the hospital to receive medical attention. The respondents only cited the police as persons in the community that they directly dealt with. This leaves one to wonder as to where the other key stakeholders such as the political leaders and the Church are doing with regard to the issue of defilement which has now reached an alarming rate in the country. In this regard, it may be "safe" to say that there is dare need for further investigation into this issue and try to find out why girls only dealt with the police on matters pertaining to defilement.

\subsection{Awareness Programmes at School, Family and Community Levels Aimed at Empowering Children with Child-Defilement Preventive Skills in Primary and Secondary Schools}

As regards to availability awareness programmes within the school, the findings of the study revealed that most of the girls that had experienced defilement argued that such programmes were non-existent in the schools. The study has also revealed that the majority of the girls that had experienced defilement had never heard of any such programmes in their communities. However for the few that stated that such programmes were available in the school, their argument was that they at least received counselling and guidance lessons from the school. However, the lack of awareness programmes on defilement in schools is a worrisome situation in that it is not known whether these girls have any skills in preventing themselves from becoming victims of defilement. The above finding is in line with Show You Care Coalition (2015) who argued that the government through its relevant offices should establish structures and mechanisms that should bring to an end gender based violence, child marriage and defilement through training and dissemination of information on preventing children from becoming victims of gender based violence including defilement.

The study further revealed that in the absence of such programmes, the girls that had experienced defilement advised the girls that have not yet fallen victims of defilement not to trust anyone including their closest own relatives. Furthermore, the girls that had experienced defilement advised those girls that had been victims of defilement that they not relent to report matters of defilement to the appropriate law enforcers. However, some of these girls were of the view that girls that had experienced defilement need to pray to God as this would help them recover from the trauma. It was further found that some of these girls were of the view that once girls fall prey to defilement, they should immediately seek medical and psychological help.

This study also revealed that $79 \%$ of the parents/guardians argued that programmes on awareness were not available in their communities. These parents/guardians argued that they have never heard of 
any such programmes; let alone, the fact that no one has been to the communities to or talk about Child Sexual Abuse (C.S.A.). However for the few parents/guardians they felt that awareness programmes were available, they disclosed that this was done through people who came to the market places and talked about it. They further argued that such programmes or interventions came as documentaries on television which they watched in their respective homes.

The head teachers and the guidance and counselling teachers/matrons on the other hand argued that awareness programmes were in place in most of the schools. They argued that they had NGOs such as the Young Christian Association which has strengthened its fight against defilement. The head teachers also argued that there are people who visit the school and gave awareness information to the girls through poems and drama to the community and school as a way of as a way of supporting the girls with data as regards to defilement. To compliment what the other head teachers said, one of the head teachers emphasised the argument thus: "We have regular counselling sessions with pupils where we talk about defilement and HIV and AIDS issues. From these programmes, pupils learn more on defilement and how to prevent themselves from becoming victims of defilement". One of the guidance and counselling teacher/matron also argued that the school has clubs such as C.R.C., SAFE, Anti-AIDS including open discussions where the pupils that had experienced defilement share freely their experiences with their colleagues. Kasonde-Ng'andu (2003) in her study on Weekly Boarding also found out that SAFE clubs/houses contributed to knowledge sharing among the pupils, especially those that were kept in such houses in boarding schools. However, one of the head teacher argued that such programmes were not there in the community and schools. This sentiment was also echoed by the community leader who argued that she has not yet seen any tangible interventions so far.

From the foregoing, it could be deduced that awareness programmes on defilement were present in schools but lacking at family and community levels. Show Care Coalition (2015) also argue that there should be increased dialogue and sensitisation of the communities to share their experiences and create an atmosphere of zero tolerance towards defilement by any member of the community. The coalition further advocated for commitment from the Ministry of Education to implement curriculum change that will include sex education as an empowerment tool for the protection of girls in school. The above revelations, therefore, need for the government through its appropriate organs to vigorously engage itself in the provision of awareness information on defilement if the Zambian populace was going to help in curbing cases of defilement. This entails training as many counsellors as possible at school, family and community levels.

\section{Conclusion}

The finding of the study have shown that the populace Zambians were aware about defilement and that their main source of information was the media. It has also shown that the main perpetrators of child defilement were male adults and male peers. Further, the study has shown that the girls that fell victims of defilement were availed counselling services in the form of educational, career, social and spiritual counselling. However, there was an outcry that teachers who provided guidance and counselling in schools were not trained.

In terms of support provision by the school, family and the community to the girls that fell victims of defilement, the findings showed that counselling was the most common type of support provided to these girls. This was achieved through clubs such as SAFE and Anti-AIDS, and peer education, including medical care.

Awareness programmes at school, family and community levels to empower children with childdefilement preventive skills in primary and secondary schools, these were not available in most schools. However, some head teachers, and guidance and counselling teachers argued that such programmes were available in most schools. They cited NGOs such as the Young Christian Association who availed such programmes to the pupils through poems and drama.

\section{RECOMMENDATIONS}

Based on the findings, the following recommendations were made:

- The Ministry of Education, Science, Vocational Training and Early Education through school administrators should engage itself in continuous vigorous educational awareness campaigns on child defilement; 
- Schools should ensure that the guidance and counselling teachers uphold confidentiality as victims need teachers who honour confidentiality as this would allow more girls to freely report cases of defilement to the appropriate authorities;

- Traditional practices that are anti-girls should be done away with. This could be achieved through community and school initiatives by working in partnership, visiting, and holding talks with traditional leaders on the evils of defilement and its consequences;

- The government through its appropriate organs should mount campaigns aimed at making the law to be consistent with reality.

\section{ACKNOWLEDGEMENT}

My sincere gratitude goes to my supervisors Dr. S. Kasonde-Ng'andu and Dr. K. Kalimaposo for their guidance throughout my writing the thesis.

\section{REFERENCES}

Ajzen, I. (1985) From Intentions to Actions: A Theory of Planned Behaviour. In J. Kuhl and Beckman (eds.), Action-Control: From Cognition to Behaviour. Heidelberg, Germany: Springer.

Ajowi, J.O. (2005). Role of Guidance and Counseling in Promoting Student Discipline in Secondary Schools in Kisumu District. Published M.Ed.Thesis. Maseno University.

American Academy of Child \& Adolescent Psychiatry. (2004). Child sexual abuse [Facts for Families]. available at http://www.aacap.org/

American Academy of Pediatrics. (2006). What is child sexual abuse? [Medical Library].

Available at http://www.medem.com/MedLB/ article_detaillb.cfm?article_ID=ZZZ1LW3YA7C

Armstrong, S. (2013). "In Kenya: A Victory for Girls and Rights". The International Herald Tribune, June 5, 2013.

Auni, R.T. (2009). Contributions of Guidance and Counseling Program on Social Adjustment of Students in Siaya District Public Secondary Schools. M.Ed. thesis. Maseno University.

Bbuku-Chuulu, M.; Chileshe, M. P.; Ntalasha, H.; Kasonde-Ng'andu, S.; Daura, M.M.; Chanda, A. (2001). Gender Violence: The Invisible Struggle - Responses to the Justice Delivery System in Zambia. Lusaka: WLSA (Zambia).

Bennett T.W. (2006). "Traditional courts and fundamental rights". In: Hinz MO, Patemann

HL, (eds). The shade of New Leaves, Governance in Traditional Authority: A South African Perspective. Berlin: Lit Verlag, 157-166.

Berliner, L., \& Elliot, D. M. (2002). Sexual abuse of children. In J. E. B. Myers, L. Berliner, J.

Briere, \& Ct. T. Hendrix (Eds.), The APSAC handbook on child maltreatment ( $2^{\text {nd }} e d$ ). (pp. 55-78). Thousand Oaks, CA: Sage Publications, Inc.

Bortei-Doku A.E. and Kuenyehia A. (1998). "Violence against women in Ghana". In: Carrol,

H.D.R. \& Ofori-Atta N.A. (1998) "Violence against women in the Gambia". In: Kuenyehia, A (ed.) Women \& law in West Africa: Situational Analysis of Some Key Issues Affecting Women. WaLWA, 250- 271.

Budrionis, R., \& Jongsma, A. E. (2003). The sexual abuse victim and sexual offender treatment planner. Hoboken, NJ: John Wiley.

Chanda, C.N. (2003). Counselling in police settings: A Zambian perspective. Lusaka: Venus Stationery.

"Child Defilement Troubles Uganda". The Journal of Turkish Weekly (JTW), September 16, 2015. USAK House, Ayten Sok. No. 21 Mebusevleri, Tandogan, Ankara / Turkey.

Chimuka, D. (2003). Sexual Violence and Coercion by Non-Family Perpetrators. WLSA Forum for African Women Educationalists, Zambia National Chapter (FAWEZA). Available at http://www.refworld.org/docid/3f4f59890.html $\neq$ P466_74720

Chuulu, B.M. et al. (1999) Women and Justice in Zambia: Myths of reality? WLSA Trust Zambia, Lusaka.

Coalition for Evidence Based Policy (2002). Bringing evidence-driven progress to education: A recommended strategy for the U.S. Department of Education. Available at http://www. excelgov.org. 
Defilement of Girls in Selected Primary and Secondary Schools in Lusaka Province: Implications for Guidance and Counselling

Crosson-Tower, C. (2002). Understanding child abuse and neglect ( $5^{\text {th }}$ ed.). Boston: Allyn and Bacon, 2002.

Darkness to Light. (2001-2005). Statistics. Available at http://www.darkness2light.org/KnowAbout/ statistics_2.asp

Deblinger, E., Stauffer, L. B., \& Steer, R. A. (2001). Comparative efficacies of supportive and cognitive behavioural group therapies for young children who have been sexually abused and their non-offending mothers. Child Maltreatment, 6 (4), 332-343.

Dove et al., (2008). "Why are child defilement cases in Zambia rising?" Available at http://allafrica.com/

Elliot, M. (2001). Why my child? A guide for parents of children who have been sexually abused. London: Kidscape. Available at http://www.kidscape.org.uk

Finkelhor, D. (1994) Current Information on the Scope and Nature of Child Sexual Abuse: the future for children 4:54-69.

Greene, J.C., Caracelli, V.J., Graham, W.F. (1989). "Towards a Conceptual Framework for MixedMethod Evaluation Design." Ducational Evaluation and Policy Analysis, 11, 255 - 274.

Gwitira, M. (2015). "Child Defilement in the Times of HIV and AIDS". UNICEF: Harare, Zimbawe. Available at: http://www.afcast.org.zw/index.php?option=com_ content\&view=article\&id=475: child-defilement-in-the-times-of-hiv-and-aids-child-defilement-in-time-of-hiv-andaids $\&$ catid $=42:$ lectures $\&$ Itemid $=293$ [accessed 24/09/15].

Haugaard, J. J. (2000). The challenge of defining child sexual abuse. American Psychologist, 55, 1036-1039.

Hopper, J. (2006). Child abuse: Statistics, research, and resources. Available at http://www. jimhopper.com/abstats http://allafrica.com/ "Why are child defilement cases in Zambia rising? Retrieved 24/01/2014.

Human Rights Watch (2003). Suffering in Silence: The Links between Human Rights Abuses and HIV Transmission to Girls in Zambia, 28 January 2003, 1564322831. Available at: http://www. refworld.org/docid/3f4f59890.html [accessed 2 October 2015].

International Journal of Academic Research and Reflection (2014). Available at: www.idpublications. org, (2014) Vol. 2, No. 4, 2014 ISSN 2309-0405.

K.I.E., (2004). Guidance and counseling: Teachers' Handbook. Nairobi: K.I.E.

Kalichman, S. C. (1993). Mandated reporting of suspected child abuse. Washington, DC: American Psychological Association.

Kamau, W. (2013). Legal Treatment of Consent in Sexual Offences in Kenya. Nairobi: University of Nairobi.

Kasonde-Ng'andu, S., Kalinda, R., Muchelemba-Banda, V. (2008). Issues Relating to Equalising Opportunities for Girls Education in Zambia. Lusaka: Forum for African Women Educationalists of Zambia (FAWEZA).

Kombo, K. and Tromp, L. A. (2006). Proposal and Thesis Writing. Nairobi: Paulines Publications Africa.

Kute, B. (2008). Role of Peer Counselors in enhancing management of Student Discipline in Public Secondary Schools in Kisumu Municipality, Kenya. Published Master's thesis. Maseno University.

Limpo, C. (2003). Defilement of Girls in Zambia. Available at: http://www.tigweb/express/ panaroma/artice.html?ContentID=1961. [accessed on Sept. 25, 2015).

Lloyd and Blanc (1996), "Children Schooling in Sub-Saharan Africa: The Role of Fathers, Mothers and Others" Population and Development Review, Vol. 22 No. 2: 265 -98.

Makumba, C.E. (2013). "The Status of Guidance and Counselling Provision in Selected Basic Schools in Mumbwa District". Published MA dissertation in Educational Psychology, University of Zambia, Lusaka.

Menick, D. \& Ngoh, F. (1999). Reconciliation and/or Mediation Settlements in Cases of Sexual Abuse of Minors in Cameroon. Med Trop (Mars), 59 (2): 161-4. 
Miller, K. L., Dove, M. K., \& Miller, S. M. (2007). A counsellor's guide to child sexual abuse: Prevention, reporting and treatment strategies. Paper based on a program presented at the Association for Counsellor Education and Supervision Conference, Columbus, $\mathrm{OH}$.

Ministry of Community Development and Social Services (2006) Report on Survey and Analysis of Street Children in Zambia; Lusaka: MCDSS.

Ministry of Education (2001). Teachers' Curriculum Manual. Lusaka: MoE.

MOEST (2004). Guidance and Counseling Module for Primary School Teachers: School Based Teacher Development (SbTD).Nairobi: Jomo Kenyatta Foundation.

Morhe, R.A.S., Morhe, E.S.K. (2013). The Law on Defilement in Ghana and Challenges in its Implementation at the Ejisu-Juabeng Domestic Violence and Victims Support Unit of the Ghana Police Service Journal of Law, Policy and Globalization, Vol.16, 2013. ISSN 2224-3240 (Paper) ISSN 2224-3259 (Online: www.iiste.org).

Morhe, R.A.S. (2011). Access to Justice and Informal Courts. VDM Verlag Dr. Muller, 130.

Mullen, P. E., \& Fleming, J. (2006). Long-term effects of child sexual abuse. [National Child Protection Clearinghouse.] Retrieved November 8, 2006. Available at http://www.aifs.gov.au/ nch/issues $9 . \mathrm{html}$

Murphy, N., Young, P. (2005). Sexuality in Children and Adolescents with Disabilities. Developmental Medicine and Child Neurology, 47, 640-644.

Muwereza, N. (2007). 'Sexual Offences Among Adolescents: A Critical Literature Review on Defilement in Uganda'. A Thesis Submitted For the Award of a Master of Philosophy in Criminological Research Institute of Criminology, Department of Psychological Criminology Cambridge University.

Mutombo, N. \& Mumbuna, M. (2010).Review of the re-entry policy. Lusaka: MoE.

Mwanja, P.N. (2003). Report Submitted in Partial Fulfilment of the Requirements for the Degree of Law (LL.B) of the University of Zambia. Lusaka: University of Zambia.

National Association to Prevent Sexual Abuse of Children (NAPSAC) and Twin City Public Television (Co-Producers). (2008). Saving children: The sex abuse tragedy [DVD]. Available at http//www.napsac.us

National Child Policy (2006). Ministry of Sport, Youth and Child Development, Zambia,Lusaka.

Nkandela, A. (2001). Rapid Incidences of Child Abuse in Zambia. Lusaka: CHIN.

Schwartz-Kennery, B.M., Mc Cauley, M.; and Epstein, M. (2001) Child Abuse: a Global View. Wesport, CT: Greenwood.

Shinkanga, M.G. (1996). Child Sexual Abuse in Zambia. Lusaka: YWCA.

Orodhlo, A. J. (2003). Essentials of Educational and Social Sciences Research Method.

Nairobi: Masola Publishers.

Phiri, J.T. (2007). Module EDGC 17: Counseling Children. Lusaka: Zambian Open University

Rape \& Sexual Abuse Center. (2002), Education statistics. Retrieved November 29, 2006. Available at http://www.rasac/education/statistics.html

Republic of Ghana (1960). Ghana Criminal Offenses Act. Available at http://www.myjoyonline.com/ news/2014/January-9th/-defilement-cases-on-the-increase-dovvsu.php (accessed on 24/09/15).

Republic of Kenya (2002a). Policy Framework for Guidance and counseling in Education.

Nairobi: Division of Policy formulation and projects.

Reynolds, S. (2000). Evidenced based practice and psychotherapy research. Journal of Mental Health, 9, 257-266.

Sedlak, A. J., \& Broadhurst, D. D. (1996). Third national incidence study of child abuse and neglect. U.S.

Department of Health and Human Services, Administration on Children, Youth and Families. To obtain contact the National Clearinghouse on Child Abuse and Neglect Information, P.O. Box 1182 Washington, D.C. 20013-1182.

Sexton, T.L. (1996). The relevance of counseling outcome research: Current trends and practical applications. Journal of Counselling and Development, 74, 950-600. 
Defilement of Girls in Selected Primary and Secondary Schools in Lusaka Province: Implications for Guidance and Counselling

Sexton, T.L. (2000). Reconstructing clinical training: In pursuit of evidence-based clinical training. Counselor Education Supervision, 39, 218-227.

Sexton, T.L., Whiston, S.C., Bleuer, J.C. \& Walz, G.R. (1997). Integrating outcome research into counselling practice and training . American Counselling Association: Alexandria, VA.

Show Care Coalition (2015). "End violence against women: a communique". Lusaka, September 12, 2015.

Siamwiza, R. and Faveri, C. (1996) Child Abuse in Zambia, Lusaka: UNICEF.

Simatwa, M. W. (2007). Management of student discipline in secondary schools in Bungoma District, Kenya. $\mathrm{PhD}$ thesis.

Thompson, J. \& Simmonds, F.N. (2012). A review of statutory sentencing provisions for rape, defilement, and sexual assault in East, Central, and southern Africa. Lusaka: Population Council.

Turner, H.A., Finkelhor, D., \& Ormrod, R. (2007). Predictors of receiving counseling in a national sample of youth: The relative influence of symptoms, victimization exposure, parent-child conflict, and delinquency. Journal of Youth and Adolescence, 36, 861-876.

Unger, R.M. (1987). Social Theory: Its situation and its task. Cambridge: Cambridge University Press.

U.S. Department of Health and Human Services, Children's Bureau of the Administration on Children, Youth and Families (2006). Child Maltreatment 2006. Available at http://www.acf. hhs.gov/programs/cb/stats_research/index.htm\#can

Wango, G. M. (2011). Counselling Psychology Legal Regulatory Framework in Kenya.

Nairobi: University of Nairobi.

Wango, G. M. (2006a). 'The Role and Function of the Secondary School Guidance and Counselling Programme', Kenya Secondary Schools Heads Association Annual Conference 2006, Unpublished Paper.

Wallen, N.E. \& Fraenkel, J.R. (1991). Educational Research: A guide to the Process. New York: McGraw-Hill.

Whiston, S.C., \& Coker, J.K. (in press). Reconstructing clinical training: Implications from research. Counsellor Education and Supervision.

Women and Law in Southern Africa (2001). Gender Violence: The Invisible Struggle. Lusaka: WLSA.

Women and Law in Southern Africa (2007). Women's Sexual and Reproductive Rights and HIV /AIDS Transmission in Zambia. Lusaka: WLSA.

Zulu, J. (2006) Sexual Abuse and Education in Zambia. Available at www.eent.org.uk/ newsletters/ news

Zambia Daily Mail Newspaper, 8.2013. 